\title{
MODUS OPERANDI TINDAK PIDANA PERBANKAN DAN UPAYA PENANGGULANGANNYA DI INDONESIA
}

\author{
Diana Kartika Suci \\ Lembaga Perlindungan Hukum dan HAM Kota Malang \\ Email : dianakartikasuci@gmail.com
}

\begin{abstract}
Abstrak
Dalam arus globalisasi tidak dapat dipungkiri bahwa dunia perbankan menjadi salah satu dari sekian penggerak ekonomi suatu bangsa tak terkecuali Indonesia yang hampir sebagian besar dalam proses transaksinya melibatkan dunia perbankan. Namun demikian ditengah arus globasi juga banyak terjadi modusmodus baru dalam dunia kriminal, baik kejahatan secara umum, kejahatan dalam dunia maya atau Cyber Crime dan terakhir adalah kejahatan yang dilakukan pada dunia perbankan yang akhir-akhir ini menyita perhatian publik mengingat jumlah kasus serupa terus berkembang dari tahun ke tahun dengan modus yang berbedabeda yang salah satunya adalah modus Operandi. Sehingga untuk mencegah terjadinya kasus ini secara terus menerus perlu dilakukan upaya pencegahan yang bersifat preventif. Dalam hasil penelitian ini penulis menawarkan empat hal guna menanggulangi tindak pidana perbankan. pertama, Perlunya peningkatan kemampuan penyidik dalam bidang akunting dan keuangan, kedua, peningkatan sistem pengawasan dari pihak bank yang lebih efektif dan ini bisa dilakukan jika proses rekruitmen pegawai lebih menekankan moralitas, ketiga, Perlunya kewenangan penyidik dalam rangka menjalankan tugasnya, bukan hanya sekedar menyangkut rahasia bank semata dan yang terakhir perlunya pembaharuan peraturan perundang-undangan dalam bidang perbankan
\end{abstract}

Kata kunci: Modus Operandi, Tindak Pidana Perbankan, Indonesia

\begin{abstract}
In the flow of globalization, it is undeniable that the banking world is one of the many economic drivers of a nation, including Indonesia, which almost all of its transactions involve the banking world. However, there are also many new modes of global crime, crime in cyberspace or cybercrime and most recently crimes committed in the banking world, which have recently caught the attention of the public considering the number of similar cases continues to grow. from year to year with different modes, one of which is the Operandi mode. So that the prevention of this case continuously requires preventive prevention measures. In the results of this study the authors offer four things in order to tackle banking crime. first, the need to increase the capacity of investigators in the field of accounting and finance, second, to improve the supervision system from the bank which is more effective and this can be done if the employee recruitment process emphasizes morality, third, the need for the authority of investigators to carry out their duties, not just the bank itself and the last is the regulatory reform in the banking sector.
\end{abstract}

Keywords: Operandi, Banking Crime, Indonesia 


\section{Jurnal Negara dan Keadilan \\ p-ISSN 2302-7010 e-ISSN 2721-9801}

\section{PENDAHULUAN}

Dalam kehidupan manusia disadari bahwa yang benar, yang indah dan yang baik itu dapat menyenangkan, membahagiakan, menentramkan, dan memuaskan manusia. Sebaliknya yang salah, yang jelek, dan yang buruk itu menyengsarakan, menyusahkan, dan membosankan manusia. Berdasarkan dua sisi yang bertolak belakang ini, manusia adalah sumber penentu yang menimbang, menilai, memutuskan untuk memilih yang paling menguntungkan (nilai moral) atau merugikan banyak orang (dalam pendekatan norma yuridis), ${ }^{1}$ termasuk untuk memilih melakukan kejahatan ataukah tidak.

Terbukti bisa di baca, bahwa kejahatan di tengah masyarakat bisa berkembang atau tidak, sejalan dengan kondisi masyarakat. Seseorang atau sekelompok orang bisa saja melakukan suatu kejahatan, yang perilakunya ini bisa disebabkan oleh alasan atau faktor tertentu. Tidak selalu sama faktor yang menyebabkan terjadinya suatu kejahatan bagi orang yang satu dengan orang lainnya. Latar belakang kehidupan atau keadaan bisa berbeda atau sama, tapi pilihan melakukan kejahatannya tidak selalu sama.

Tindak pidana atau kejahatan bukanlah merupakan peristiwa hereditir (bawaan sejak lahir,warisan), juga bukan merupakan warisan biologis. Tingkah laku kriminal itu bisa dilakukan oleh siapapun juga, baik wanita maupun pria, dapat berlangsung pada usia anak, dewasa ataupun lanjut umur. Tindak kejahatan bisa dilakukan secara sadar, yaitu difikirkan, direncanakan dan diarahkan pada suatu maksud tertentu dengan kesengajaan. ${ }^{2}$ Adapun kerugian yang diderita seseorang atau masyarakat dijadikan sebagai tolok ukur adanya kejahatan. Meskipun demikian, kerugian juga tidak selalu menjadi ukuran dalam suatu tindak kejahatan.

Beragam kejahatan terjadi di tengah masyarakat, yang keragaman ini menandakan keragaman kepentingan. Kalau kepentingan masyarakat tidak beragam dengan segala jenis kondisi yang melatarbelakanginya, maka kejahatan pun tidak akan beragam.

Problem kejahatan atau kriminalitas bukanlah masalah yang sederhana terutama bagi masyarakat yang mengalami perkembangan sosial ekonomi seperti di di alami oleh Indonesia saat ini. Di dalam proses pelaksanaan pembangunan nasional banyak sekali faktor penunjang yang diperlukan guna mencapai keberhasilan pembangunan, namun demikian, banyak pula faktor yang mempengaruhi seseorang menjadi gagal menyesuaikannya, sehingga menempuh cara-cara yang berlawanan dengan norma hukum yang berlaku.

Faktor penunjang dalam pembangunan antara lain: faktor modal, tempat/lahan, waktu, tenaga, peran serta masyarakat, dan selain faktor penunjang tersebut diatas ada faktor yang sangat penting dan sangat berpengaruh dalam menentukan keberhasilan pembangunan yaitu faktor keamanan. Dari aspek keamanan ini, hak-hak anggota masyarakat tetap bisa terjaga dengan baik. Jika keamanannya terganggu, maka ada hak-hak yang menjadi korban. Ketika

\footnotetext{
${ }^{1}$ Abdulkadir Muhammad, Etika Profesi Hukum, Citra Adtya, Bandung, 1997, hal. 1-2.

2 Abdul Wahid, Kriminologi dan Kejahatan Kontemporer, Visipres dan Lembaga Penerbitan Fakultas Hukum Unisma, Malang, hal. 45.
} 


\section{$\mathcal{H}$ urnal Negara dan Keadilan \\ p-ISSN 2302-7010 e-ISSN 2721-9801}

keamanan terganggu, maka jelas ada pihak yang dirugikannya baik secara mater ataupnun non materi.

Faktor keamanan sangatlah penting artinya, sebab dari keseluruhan faktor penunjang yang ada tidak akan mungkin berhasil dengan baik dalam pelaksanaan pembangunan tanpa di dukung dengan situasi keamanan yang kondusif di tengah masyarakat. Di samping pembangunan nasional, juga dibutuhkan situasi keamanan yang kondusif. Di dalam pembangunan nasional itu sendiri juga bertujuan untuk semakin meningkatkan suasana aman dan tertib dalam rangka mewujudkan adanya kesejahteraan bangsa. Keamanan dan kondusif merupakan cermin stabilnya atau amannya kehidupan dalm masyarakat, khususnya dari gangguan kejahatan atau kriminalitas.

Kenyataan yang mudah diketahui dewasa ini adalah jumlah perilaku kejahatan/angka kriminalitas menunjukkan peningkatan dari tahun ke tahun baik peningkatan kuantitas maupun kualitas kejahatan berikut jenisnya. Peningkatan kejahatan ini meliputi modus operandi, peralatan yang dipergunakan, serta sasaran tindak kejahatan. Pelaku kejahatan cenderung semakin berani dan terangterangan di dalam melakukan aksinya sehinggga sangat meresahkan masyarakat.

Ada perbuatan yang dinilai merugikan seperti menggangu dan merugikan sesama manusia sudah disebut sebagai tindak kejahatan. Masyarakat akhirnya gampang memberikan julukan pada seseorang yang sering menggangu atau merugikan orang lain dengan sebutan sebagai "orang jahat" atau pelaku kriminalitas. Penjahat perbankkan termasuk dalam kategori penjahat yang memberikan kerugian yang tidak sedikit.

Menurut data yang didapat oleh Bank Indonesia (BI), setiap tahunnya tingkat kejahatan perbankan mengalami kenaikan yang cukup signifikan. Pada Mei 2012 ada 1009 kasus fraud yang terjadi dengan nilai kerugian 2,37 milyar. Jenis kejahatan yang terbanyak adalah pencurian identitas dan card not present dengan jumlah 402 dan 458 kasus. Dari 18 penerbit kartu kredit, kerugian diperkirakan mencapai hampir 2 milyar rupiah. ${ }^{3}$

Lebih-lebih jika tindak kejahatan itu bukan dilakukan oleh perorangan atau secara individual seperti yang secara umum terjadi dalam kejahatan perbankkan, tetapi dilakukan secara terorganisir, maka umumnya tindak kejahatan yang terjadi dapat berakibat fatal bagi kehidupan seseorang yang menjadi korbannya atau kehidupan masyarakat. Tindak kejahatan semacam ini biasanya didahului oleh suatu perencanaan yang matang, seperti bagaimana harus menghilangkan jejak dan mendapatkan harta yang diinginkan. Jika ini dilakukan terhadap kawasan hutan, maka bagaimana bisa menghilangkan jejak dari kejaran pihak yang berwajib.

Sebagai contoh kasus, bahwa tahun 2004 merupakan tahun kelabu bagi industri perbankan dan lembaga pengawas bank. Tahun tersebut ditutup dengan terungkapnya skandal Bank Global Tbk. Pengurus dan sekaligus pemilik bank tersebut melakukan praktik tidak patut dilakukan oleh seorang bankir dan merupakan tindakan kriminal jika dilihat dari kacamata hukum. Serangkaian praktik memalukan dan berbau kriminal telah terjadi di bank tersebut. Mulai dari tidak bersedia memberikan dokumen dan tidak mau memberikan keterangan kepada pengawas, berupaya memusnahkan dokumen sampai menerbitkan surat

\footnotetext{
${ }^{3}$ http://ridwanaz.com/umum/ekonomi/modus-kejahatan-perbankan/, akses 19 Juni 2019.
} 


\section{Jurnal Negara dan $\mathcal{X}$ eadilan \\ p-ISSN 2302-7010 e-ISSN 2721-9801}

berharga fiktif Sepak terjang Bank Global berakhir dengan pembekuan dan pada 13 Januari 2005 dicabut ijin usahanya.

Bank Global bukan satu-satunya skandal yang melanda industri perbankan sepanjang 2004. Sebelumnya ada Bank Asiatic dan Bank Dagang Bali yang menurut pengawas juga melakukan tindakan yang tidak patut, mengalami kerugian besar dan akhirnya ijin usaha keduanya dicabut. Dalam tahun-tahun sebelumnya juga tidak sepi dari perilaku bankir yang melanggar hukum. Skandal Bank BNI yang mengakibatkan kerugian negara sebesar Rp 1.7 Triliun sampai saat ini masih dalam proses persidangan yang tak kunjung usai. Sebelumnya praktik pengelolaan bank yang tidak berhati-hati, perbuatan curang bahkan praktik berunsur pidana mewarnai wajah industri perbankan. Komisaris dan Direktur PT. Bank Citra misalnya melakukan perbuatan kriminal, yaitu tidak melaksanakan langkah-langkah yang diperlukan untuk memastikan ketaatan bank terhadap ketentuan Undang-Undang Perbankan dan ketentuan peraturan perundangundangan lainnya yang berlaku bagi bank. Hanya saja hakim bermurah hati dengan menjatuhkan hukuman yang sangat ringan. ${ }^{4}$

\section{METODE PENELITIAN}

Penelitian ini menggunakan jenis penelitian bersifat deskriptif, dimana penelitian ini memberikan data yang seteliti mungkin tentang manusia, keadaan atau gelala-gejala lainnya. Berdasarkan bahan hukum yang digunakan dalam penelitian, penelitian ini mengunakan pendekatan yuridis normatif. Pendekatan tersebut dilakukan dengan cara meneliti bahan pustaka atau data sekunder. Penelitian ini dapat juga dinamakan penelitian hukum kepustakaan

\section{PEMBAHASAN}

\section{Modus Operandi Tindak Pidana Perbankan}

Sebagai deskripsi kasus, bahwa bobolnya Bank BNI dengan jumlah cukup spektakular yang kemudian di susul dengan adanya "perampokan” Bank Rakyat Indonesia (BRI). Kasus ini mempertebal kepercayaan kita akan rendahnya etika profesionalisme pengelola industri perbankan dan lemahnya sistem pengawasan bank terutama sistem pengawasan internal bank itu sendiri. Padahal etika profesionalisme sangat penting bagi pengelolaan bank karena pada dasarnya kekayaan yang dikelola oleh pengurus bank sebagian besar merupakan kekayaan masyarakat yang dipercayakan padanya. Pada tahun-tahun terakhir ini perbankan memang telah mengalami suatu ujian yang sangat berat terutama dalam profesionalisme kepengurusan bank. Sebenarnya hal tersebut tidak hanya terjadi pada industri perbankan Indonesia tetapi juga pada industri perbankan di luar negeri. Hal ini dapat dilihat dari besarnya kerugian yang diderita oleh bank multinasional yang disebabkan oleh pengurus bank.

4 Zulkornain Sitompul, Memberantasa Kejahatan Perbankkan, Tantangan Pengawas Bank, http://zulsitompul.files.wordpress.com/2007/06/makalah_kejahatan-perbankanjhb.pdf, akses 24 Juni 2019. 


\section{$\mathcal{H}$ urnal Negara dan Keadilan \\ p-ISSN 2302-7010 e-ISSN 2721-9801}

Disamping penipuan yang dilakukan oleh orang dalam perbankan, bentuk transaksi bank telah pula menyebabkan perbankan dapat digunakan sebagai sarana untuk menyembunyikan dan atau mengaburkan asal usul dana yang berasal dari tindak pidana. Upaya pengaburan ini dikenal dengan pencucian uang (money laundering) yang beberapa tahun terakhir ini semakin menjadi sorotan internasional. Hal ini tidak terlepas dari semakin meningkatnya tindak kejahatan money laundering yang secara langsung maupun tidak langsung dapat mempengaruhi sistem ekonomi suatu negara.

Dalam pandangan E. Utrecht, hukum itu adalah himpunan peraturanperaturan yang di dalamnya memuat (perintah -perintah dan larangan-larangan) yang mengurus tata tertib sutu masyarakat dan karena itu harus ditaati oleh masyarakat itu. S.M. Amin mengartikan hukum sebagai berikut "kumpulan peraturan-peraturan yang terdiri dari norma dan sanksi-sanksi itu disebut hukum dan tujuan hukum itu adalah mengadakan ketatatertiban dalam pergaulan manusia, sehingga kemanan dan ketertiban terpelihara". ${ }^{5}$ Salah satu dari aturan yang seharusya ditaati masayarakat ini adalah UU No. 10 Tahun 1998 tentang Perbankan.

UU No. 10 Tahun 1998 tentang Perbankan juga secara tidak langsung sama dengan pandangan JCT Simorangkir dan Woerjono Sastro Pranoto yang menyebut, bahwa hukum itu ialah peraturan-peraturan yang bersifat memaksa, yang menentukan tingkah laku manusia dalam lingkungan masyarakat yang dibuat oleh badan-badan resmi yang berwajib, pelanggaran mana terhadap peraturanperaturan atau regulasi tadi berakibat diambilnya tindakan yaitu dengan hukuman tertentu. Hukum ialah semua aturan (norma) yang harus dituruti dalam tingkah laku, tindakan-tindakan dalam pergaulan hidup dengan ancaman mesti mengganti kerugian, jika melanggar aturan-aturan itu akan membahayakan diri sendiri atau harta, umpamanya orang akan kehilangan kemerdekaannya, di denda dan sebagainya. ${ }^{6}$

Secara yuridis, perbankan adalah segala sesuatu yang menjangkau tentang bank, yang mencakup kelembagaan, kegiatan usaha, serta cara dan proses dalam melaksanakan kegiatan usahanya, seperti yang tercantum dalam Pasal 1 angka 1 Undang-Undang No. 10 Tahun 1998. Berdasarkan Pasal 6 UU No. 7 Tahun 1992 jo UU No. 10 Tahun 1998 tentang Perbankan, kegiatan bank umum meliputi:

a. Menghimpun dana dari masyarakat dalam bentuk simpanan berupa giro, deposito berjangka, sertifikat deposito,, tabungan dan atau bentuk lainnya yang dipersamakan dengan itu;

b. Memberikan kredit;

c. Menerbitkan surat pengakuan utang;

d. Membeli, menjual atau menjamin atas risiko sendiri maupun untuk kepentingan dan atas perintah nasabahnya:

1. Surat-surat wesel termasuk wesel yang diakseptasi oleh bank yang masa berlakunya tidak lebih lama daripada kebiasaan dalam perdagangan suratsurat dimaksud;

${ }^{5}$ CST. Kansil, Pengantar Ilmu Hukum dan Tata Hukum Indonesia, Balai Pustaka, Jakarta, 2000, hal. 6 .

${ }^{6} \mathrm{Ibid}$, hal. 11-12. 


\section{Zurnal Negara dan $\mathcal{X}$ eadilan \\ p-ISSN 2302-7010 e-ISSN 2721-9801}

2. Surat pengakuan hutang, dan kertas dagang lainnya yang masa berlakunya tidak lebih lama dari kebiasaan dalam perdagangan surat-surat dimaksud;

3. Kertas perbendaharaan negara, dan surat jaminan pemerintah;

4. Sertifikat Bank Indonesia (SBI);

5. Obligasi;

6. Surat dagang berjangka waktu sampai dengan 1 (satu) tahun;

7. Instrumen surat berharga lain yang berjangka waktu sampai dengan 1 (satu) tahun.

e. Memindahkan uang baik untuk kepentingan sendiri maupun untuk kepentingan nasabah;

f. Menempatkan dana pada, meminjam dana dari, atau meminjamkan dana kepada bank lain, baik dengan menggunakan surat, sarana telekomunikasi maupun dengan wesel unjuk, cek atau sarana lainnya;

g. Menerima pembayaran atas tagihan surat berharga dan melakukan perhitungan dengan atau antar pihak ketiga;

h. Menyediakan tempat untuk menyimpan barang, dan surat berharga;

i. Melakukan kegiatan penitipan untuk kepentingan pihak lain berdasarkan suatu kontrak;

j. Melakukan penempatan dana dari nasabah kepada nasabah lainnya adalam bentuk surat berharga yang tidak tercatat di bursa efek;

k. Membeli melalui pelelangan agunan baik semua maupun sebagian dalam hal debitur tidak memenuhi kewajibannya kepada bank, dengan ketentuan agunan yang dibeli tersebut wajib dicairkan secepatnya;

1. Melakukan kegiatan anjak piutang, usaha kartu kredit, dan kegiatan wali amanat;

m. Menyediakan pembiayaan dan atau melakukan kegiatan lain berdasarkan prinsip syariah, sesuai dengan ketentuan yang ditetapkan oleh Bank Indonesia;

n. Melakukan kegiatan lain yang lazim dilakukan oleh bank sepanjang tidak bertentangan dengan undang-undang ini dan peraturan perundang-undangan yang berlaku.

Semua bentuk kegiatan di atas merupakan kegiatan perbankan dalam keadaan normal atau yang seharusnya dilakukan oleh bank. Akan tetapi terdapat kegiatan perbankan memiliki motif tertentu sehingga melampaui atau tidak sesuai dengan ketentuan yang berlaku. Kegiatan semacam ini disebut tindak pidana perbankan. Tindak pidana perbankan yang dapat dilakukan dalam serangkaian kegiatan perbankan tersebut berkaitan dengan sistem keamanan dalam menjalankan setiap aktivitasnya. Sistem keamanan tidak hanya menyangkut sumberdaya manusianya saja, akan tetapi juga infrastruktur yang sampai sekarang terus berkembang, ${ }^{7}$.

Terdapat perbedaan penggunaan istilah dalam tindak pidana perbankan, misalnya kejahatan di bidang perbankan, kejahatan perbankan, kejahatan terhadap perbankan, dan tindak pidana perbankan. Perbedaan istilah ini berkembang sampai kepada pengertian kejahatan perbankan. Kejahatan perbankan bisa diartikan sebagai tindak pidana "di bidang perbankan" yang dalam pengertian ini mencakup segala perbuatan yang melanggar hukum yang ada kaitannya dengan

${ }^{7}$ Agus Raharjo, Kejahatan Perbankkan dan Penanggulangannya, http://akuntansiuntuksemua.blogspot.com/2011/05/kejahatan-perbankan.html, akses 15 Juni 2020. 


\section{$\mathcal{H}$ urnal Negara dan Keadilan \\ p-ISSN 2302-7010 e-ISSN 2721-9801}

bisnis perbankan. Dalam pengertian ini pula tercakup bank sebagai pelaku dan bank sebagai korban. ${ }^{8}$

UU No. 10 Tahun 1998 tidak secara rinci merumuskan tentang pengertian tindak pidana perbankan. Dalam UU ini hanya mengkategorikan beberapa perbuatan yang termasuk ke dalam kejahatan dan di satu pihak bisa dikategorikan sebagai suatu pelanggaran. Akan tetapi ada juga yang memberikan pengertian tindak pidana perbankan dengan tindak pidana di bidang perbankan. Tindak pidana di bidang perbankan adalah segala jenis perbuatan melanggar hukum yang berhubungan dengan kegiatan dalam menjalankan usaha bank, baik bank sebagai sasaran maupun sebagai sarana, sedangkan tindak pidana perbankan (banking crime) merupakan tindak pidana yang dilakukan oleh bank. ${ }^{9}$

Kejahatan di bidang perbankan adalah kejahatan apapun yang menyangkut perbankan, misalnya seseorang merampok bank adalah kejahatan di bidang perbankan, begitu pula pengalihan rekening secara tidak sah adalah kejahatan di bidang perbankan, jadi pengertiannya sangat luas. Sedangkan kejahatan perbankan adalah bentuk perbuatan yang telah diciptakan oleh undang-undang perbankan yang merupakan larangan dan keharusan untuk ditaati, misalnya larangan mendirikan bank gelap dan pembocoran rahasia bank. Perbedaan istilah ini menyebabkan atau berpengaruh terhadap penegakan hukum. Kejahatan perbankan akan ditindak melalui ketentuan pidana yang diatur dalam undangundang perbankan, sedangkan kejahatan di bidang perbankan ditindak melalui undang-undang di luar undang-undang perbankan. ${ }^{10}$

Pemakaian istilah tindak pidana di bidang perbankan belum ada kesamaan pendapat. Badan Pembinaan Hukum Nasional (BPHN), dan Departemen Kehakiman memberikan pengertian yang berbeda untuk kedua tindak pidana dibidang perbankan, yaitu: ${ }^{11}$

a. Tindak pidana perbankan adalah:

Setiap perbuatan yang melanggar ketentuan peraturan perundang-undangan sebagaimana diatur dalam UU No. 7 Tahun 1992 tentang perbankan telah diubah dengan UU No. 10 Tahun 1998.

Tindak pidana yang dilakukan dalam menjalankan fungsi dan usahanya sebagai bank berdasarkan UU Perbankan.

b. Tindak pidana di bidang perbankan adalah:

Segala jenis perbuatan yang melanggar hukum yang berhubungan dengan kegiatan dalam menjalankan usaha bank, baik bank sebagai sasaran maupun sebagai sarana.

Tindak pidana yang tidak hanya mencakup pelanggaran terhadap UndangUndang Perbankan saja, melainkan mencakup pula tindak pidana penipuan, penggelapan, pemalsuan, dan tindak pidana lain sepanjang berkaitan dengan lembaga perbankan. hal. 139.

${ }^{8}$ Edi Setiadi dan Rena Yulia. Hukum Pidana Ekonomi. Yogyakarta: Graha Ilmu, 2010,

${ }^{9}$ Ibid, hal. 140 .

${ }^{10} \mathrm{Ibid}$.

${ }^{11}$ Buletin BI, Hukum Perbankan dan Kebanksentralan, ISSN, Jakarta, 2012, hlm. 2. 


\section{Zurnal Negara dan $\mathcal{X}$ eadilan \\ p-ISSN 2302-7010 e-ISSN 2721-9801}

Sebagai tindak preventif maupun represif perlu dikemukakan bahwa tindak pidana perbankan yang terdapat dalam hukum positif di Indonesia, karena perkembangan terakhir menunjukkan banyaknya terjadi permasalahanpermasalahan atau kasus di dunia dan perbankan Indonesia, yang pengaruhnya cukup besar di kalangan masyarakat, dunia usaha, maupun dalam hubungan kerjasama dengan luar negeri.

Undang-Undang Perbankan menetapkan 13 definisi dari pasal 46 sampai dengan Pasal 50A mengenai suatu tindak pidana perbankan. Ketiga belas kejahatan perbankan tersebut dapat digolongkan ke dalam 4 macam yaitu: ${ }^{12}$

a. Tindak pidana yang berkaitan dengan perizinan. Pasal 46 ayat (1) dan ayat (2) Undang-Undang Perbankan.

b. Tindak pidana yang berkaitan dengan rahasia bank. Pasal 47 ayat (1) dan ayat (2) Undang-Undang Perbankan.

c. Tindak pidana yang berkaitan dengan pengawasan dan pembinaan. Pasal 48 ayat (1) dan ayat (2) Undang-Undang Perbankan.

d. Tindak pidana yang berkaitan dengan usaha bank. Pasal 49 ayat (1) dan ayat (2) Undang-Undang Perbankan.

Adapun mengenai berbagai bentuk atau modus operandi kejahatan (tindak pidana) perbankan antara lain meliputi:

a. Pelanggaran/penghindaran pajak

b. penipuan/kecurangan di bidang perkreditan,

c. Penggelapan dana (masyarakat),

d. Penyalahgunaan atau penyelewengan dana masyarakat,

e. pelanggaran terhadap aturan keuangan,

f. penipuan transaksi tanah

g. delik-delik lingkungan, atau pencucian uang, dan sebagainya.

Indryanto Senoadji melihat tindak pidana perbankan dalam dua sisi pengertian, yakni dalam pengertian sempit dan dalam pengertian luas. Dalam pengertian yang disebut pertama, tindak pidana perbankan hanya terbatas kepada perbuatan yang dikategorikan sebagai perbuatan pidana menurut UU No. 7 Tahun 1992 saja (lihat Pasal 49). Sementara pengertian disebut terakhir ialah pidana perbankan yang tidak terbatas hanya kepada yang di atur oleh UU Perbankan saja, tetapi tindak pidana demikian merupakan bagian dari tindak pidana ekonomi yang diatur UU No. 7 (Darurat) Tahun 1955 dengan perkecualian UU kepabeanan dalam UU No.10 Tahun 1997.

Penggolongan tindak pidana bank ke dalam kejahatan didasarkan pada pengenaan ancaman hukuman yang lebih berat dibandingkan dengan pelanggaran. Hal ini mengingat bahwa bank adalah lembaga yang menyimpan dana yang dipercayakan masyarakat kepadanya, sehingga perbuatan yang dapat mengakibatkan rusaknya kepercayaan masyarakat kepada bank, yang pada dasarnya juga akan merugikan bank maupun masyarakat, perlu selalu dihindarkan.

\footnotetext{
${ }^{12}$ Sitompul, Menberantas kejahatan Perbankan: tantangan pengawasan bank, diakses dari http://zulsitompul.files.wordpress.com/2007/06/ makalah_kejahatan-perbankanjhb.pdf, pada tanggal 24 Juni 2020.
} 


\section{$\mathcal{H}$ urnal Negara dan Keadilan \\ p-ISSN 2302-7010 e-ISSN 2721-9801}

Kejahatan perbankan semakin meningkat dari waktu ke waktu dikarenakan oleh banyak hal. Empat hal yang utama adalah; pertama, pelaku yakin sering terjadi ketidak hati-hatian dalam adminisrasi internal perbankan.Kedua, lemahnya pengawasan internal. Ketiga,bank seringkali menutup-nutupi jika terjadi pelanggaran hukum di banknya untuk menjaga reputasi bank sehingga pelakunya dirahasiakan dan tidak diselesaikan melalui jalur peradilan. Keempat, adanya kolusi diantara para bankir itu sendiri. ${ }^{13}$

Tindak pidana perbankan pada umumnya dapat terjadi dengan berbagai cara atau modus. Sejalan dengan perkembangan kemajuan ilmu pengetahuan dan teknologi, maka tidak dapat disangkal pula bermunculannya modus baru di bidang kejahatan perbankan sehingga dikenal berbagai macam kejahatan perbankan di dunia dan di Indonesia pada khususnya. ${ }^{14}$

Penyalahgunaan kredit, kredit macet, pimpinan atau pengurus bank melarikan uang nasabah, mendirikan sejenis usaha perbankan tanpa ijin, pemalsuan giro atau tabungan, pemalsuan letter of credit dan lain-lainnya merupakan sebagian banyak contoh dari tindak pidana di bidang perbankan yang umumnya dikenal dan terjadi di Indonesia.

Dalam kaitannya dengan kejahatan perbankkan atau tindak pidana perbankkan, ketentuan Undang-Undang No. 10 Tahun 1998 tentang Perbankan tidak menjelaskan atau mendefinisikan secara jelas terkait dengan tindak pidana di atas, namun demikian dalam UU perbankkan setidaknya terdapat tiga belas macam tindak pidana yang diatur mulai dari Pasal 46 sampai dengan Pasal 50A. dari ketiga belas tindak pidana tersebut dapat digolongkan ke dalam empat kriteria sebagai berikut:

\section{Kejahatan Yang Berkaitan Dengan Perizinan}

Dalam ketentuan Pasal 46 ayat (1) UU Perbankan paling sering menimbulkan permasalahan yaitu: Pertama, apakah yang dimaksud dengan "menghimpun dana dari masyarakat". Kedua, apakah simpanan yang dimaksudkan dalam pasal ini hanya berupa giro, tabungan, deposito dan sertifikat deposito atau juga meliputi bentuk lain yang dipersamakan dengan itu. Ketiga, apakah si pelaku harus menggunakan nama bank atau tidak. Jawaban atas pertanyaan di atas dapat di lihat pada putusan pengadilan yang menerapkan Pasal 46 yaitu dalam kasus PT BMA yang berkedok sebagai usaha Multi Level Marketing. PT BMA menghimpun dana dari masyarakat dalam bentuk yang kurang jelas. Kepada penyimpan dana diberikan seperangkat tekstil dan atau hak untuk meminjam sejumlah uang. Menurut Bank Indonesia, MLM ini telah melakukan kegiatan bank gelap yang melanggar Pasal 46 UU Perbankan. Pendapat diterima oleh pengadilan.

\section{Kejahatan Yang Berkaitan Dengan Rahasia Bank}

Bank dikenal sebagai lembaga kepercayaan. Untuk menjaga kepercayaan tersebut diberlakukan ketentuan rahasia bank yang pelanggaran atasnya diancam dengan pidana penjara. Pasal 47 ayat (1) UU Perbankan menyebutkan bahwa

${ }^{13}$ Ibid.

14 Pratywi Precilia Soraya, Pencegahan Dan Pemberantasan Kejahatan Perbankan Melalui Sarana Pengawasan Lex Crimen Vol. II/No. 2/Apr-Jun/2013, hal. 1. 


\section{Zurnal Negara dan $\mathcal{X}$ eadilan \\ p-ISSN 2302-7010 e-ISSN 2721-9801}

barang siapa tanpa membawa perintah tertulis atau izin dari pimpinan Bank Indonesia sebagaimana dimaksud dalam Pasal 41, Pasal 41A, dan Pasal 42, dengan sengaja memaksa bank atau Pihak yang terafiliasi untuk memberikan keterangan sebagaimana dimaksud dalam Pasal 40, diancam dengan pidana penjara sekurang-kurangnya 2 (dua) tahun dan paling lama 4 (empat) tahun serta denda sekurang-kurangnya Rp. 10.000.000.000,00 (sepuluh miliar rupiah) dan paling banyak Rp. 200.000.000.000,00 (dua ratus miliar rupiah).

Ayat (2) Anggota Dewan Komisaris, Direksi, pegawai bank atau Pihak Terafiliasi lainnya yang dengan sengaja memberikan keterangan yang wajib dirahasiakan menurut Pasal 40, diancam dengan pidana penjara sekurangkurangnya 2 (dua) tahun dan paling lama 4 (empat) tahun serta denda sekurangkurangnya Rp. 4.000.000.000,00 (empat miliar rupiah) dan paling banyak Rp. 8.000.000.000,00 (delapan miliar rupiah).

Pasal 47A. UU Perbankan menyebutkan bahwa Anggota Dewan Komisaris, Direksi, atau pegawai bank yang dengan sengaja tidak memberikan keterangan yang wajib dipenuhi sebagaimana dimaksud dalam Pasal 42A dan Pasal 44A, diancam dengan pidana penjara sekurang-kurangnya 2 (dua) tahun dan paling lama 7 (tujuh) tahun serta denda sekurang-kurangnya Rp. 4.000.000.000,00 (empat miliar rupiah) dan paling banyak Rp. 15.000.000.000,00 (lima belas miliar rupiah)

\section{Kejahatan Yang Berkaitan Dengan Pengawasan Dan Pembinaan Bank}

Pasal 48 ayat (1) UU Perbankan menyebutkan bahwa Anggota Dewan Komisaris, Direksi, atau pegawai bank yang dengan sengaja tidak memberikan keterangan yang wajib dipenuhi sebagaimana dimaksud dalam Pasal 30 ayat (1) dan ayat (2) dan Pasal 34 ayat (1) dan ayat (2), diancam dengan pidana penjara sekurang-kurangnya 2 (dua) tahun dan paling lama 10 (sepuluh) tahun serta denda sekurang-kurangnya Rp. 5.000.000.000,00 (lima miliar rupiah) dan paling banyak Rp. 100.000.000.000,00 (seratus miliar rupiah).

Ayat (2) UU Perbankan menyebutkan bahwa, Anggota Dewan Komisaris, Direksi, atau pegawai bank yang lalai memberikan keterangan yang wajib dipenuhi sebagaimana dimaksud dalam Pasal 30 ayat (1) dan ayat (2) dan Pasal 34 ayat (1) dan ayat (2), diancam dengan pidana kurungan sekurang-kurangnya 1 (satu) tahun dan paling lama 2 (dua) tahun dan atau denda sekurang-kurangnya Rp. 1.000.000.000,00 (satu miliar rupiah) dan paling banyak Rp. 2.000.000.000,00 (dua miliar rupiah).

\section{Kejahatan Yang Berkaitan Dengan Usaha Bank}

Pasal 49 Ayat (1) UU tentang Perbankan menyebutkan bahwa, Anggota Dewan Komisaris, Direksi, atau pegawai bank yang dengan sengaja :

a. membuat atau menyebabkan adanya pencatatan palsu dalam pembukuan atau dalam laporan, maupun dalam dokumen atau laporan kegiatan usaha, laporan transaksi atau rekening suatu bank;

b. menghilangkan atau tidak memasukkan atau menyebabkan tidak dilakukannya pencatatan dalam pembukuan atau dalam laporan, maupun dalam dokumen atau laporan kegiatan usaha, laporan transaksi atau rekening suatu bank; 


\section{Zurnal Negara dan $\mathcal{X}$ eadilan \\ p-ISSN 2302-7010 e-ISSN 2721-9801}

c. mengubah dengan cara mengaburkan, menyembunyikan, menghapus, atau menghilangkan adanya suatu pencatatan dalam pembukuan atau dalam laporan, maupun dalam dokumen atau laporan kegiatan usaha, laporan transaksi atau rekening suatu bank, atau dengan sengaja mengubah, mengaburkan, dengan menghilangkan, menyembunyikan atau merusak catatan pembukuan tersebut, diancam dengan pidana penjara sekurangkurangnya 5 (lima) tahun dan paling lama 15 (lima belas) tahun serta denda sekurang-kurangnya Rp. 10.000.000.000,00 (sepuluh miliar rupiah) dan paling banyak Rp. 200.000.000.000,00 (dua ratus miliar rupiah).

d. Ayat (2) Pasal 49 UU Perbankan menyebutkan bahwa, Anggota Dewan Komisaris, Direksi atau pegawai bank yang dengan sengaja :

e. meminta atau menerima, mengizinkan atau menyetujui untuk menerima suatu imbalan, komisi, uang tambahan, pelayanan, uang atau barang berharga, untuk keuntungan pribadinya atau untuk keuntungan keluarganya, dalam rangka mendapatkan atau berusaha mendapatkan bagi orang lain dalam memperoleh uang muka, bank garansi, atau fasilitas kredit dari bank, atau dalam rangka pembelian atau pendiskontoan oleh bank atas surat-surat wesel, surat promes, cek, dan kertas dagang atau bukti kewajiban lainya, ataupun dalam rangka memberikan persetujuan bagi orang lain untuk melaksanakan penarikan dana yang melebihi batas kreditnya pada bank;

f. tidak melaksanakan langkah-langkah yang diperlukan untuk memastikan ketaatan bank terhadap ketentuan dalam undang-undang ini dan ketentuan peraturan perundang-undangan lainya yang berlaku bagi bank, diancam dengan pidana penjara sekurang-kurangnya 3 (tiga) tahun dan paling lama 8 (delapan) tahun serta denda sekurang-kurangnya Rp. 5.000.000.000,00 (lima miliar rupiah) dan denda paling banyak Rp. 100.000.000.000,00 (seratus miliar rupiah).

Selanjutnya, Pasal 50 UU Perbankan menyebutkan bahwa, Pihak Terafiliasi yang dengan sengaja tidak melaksanakan langkah-langkah yang diperlukan untuk memastikan ketaatan bank terhadap ketentuan dalam Undangundang ini (UU Perbankan) dan peraturan perundang-undangan lainnya yang berlaku bagi bank, diancam dengan pidana penjara sekurangkurangnya 3 (tiga) tahun dan paling lama 8 (delapan) tahun serta denda sekurangkurangnya Rp. 5.000.000.000,00 (lima miliar rupiah) dan paling banyak Rp. 100.000.000.000,00 (seratus miliar rupiah).

Pasal 50A. UU Perbankan menyebutkan bahwa, Pemegang saham yang dengan sengaja menyuruh Dewan Komisaris, Direksi, atau pegawai bank untuk melakukan atau tidak melakukan tindakan yang mengakibatkan bank tidak melaksanakan langkah-langkah yang diperlukan untuk memastikan ketaatan bank terhadap ketentuan dalam undang-undang ini dan ketentuan perundang-undangan lainnya yang berlaku bagi bank, diancam dengan pidana penjara sekurangkurangnya 7 (tujuh) tahun dan paling lama 15 (limabelas) tahun serta denda sekurang-kurangnya Rp. 10.000.000.000,00 (sepuluh miliar rupiah) dan paling banyak Rp. 200.000.000.000,00 (dua ratus miliar rupiah).

\section{Upaya Penanggulangan Tindak Pidana Perbankan}

Kejahatan atau tindak pidana merupakan suatu perbuatan yang dapat menimbulkan penderitaan, sehingga harus di cegah atau ditanggulangi. Akan 


\section{Zurnal Negara dan $\mathcal{X}$ eadilan \\ p-ISSN 2302-7010 e-ISSN 2721-9801}

tetapi mencegah atau menanggulangi kejahatan tidaklah mudah atau di samakan begitu saja langkahnya untuk setiap kejahatan. Kejahatan atau tindak pidana perbankan misalnya, tak bisa dicegah atau ditanggulangi dengan cara-cara biasa sebagaimana tindak pidana pada umumnya. ${ }^{15}$

Kejahatan atau tindak pidana perbankan memiliki karakteristik yang khas, yang membedakan dengan tindak pidana lain, sehingga harus dicegah dan ditanggulangi dengan cara-cara yang khas pula. Oleh karena keadaan yang seperti itu, maka kendala selalu muncul dalam upaya mencegah dan menanggulangi kejahatan perbankan. Sitompul, ${ }^{16}$ mengidentifikasi beberapa kendala dalam penanganan tindak pidana perbankan, yaitu:

1. Belum adanya kesamaan pandang tentang penggunaan dokumen fotokopi sebagai barang bukti dan dalam menetapkan undang-undang atau ketentuan yang dilanggar dalam tindak pidana bank;

2. Tingkat pemahaman para penegak hukum terhadap kegiatan/operasional perbankan yang berbeda-beda dan belum merata serta lemahnya koordinasi dalam penanganan kasus perbankan;

3. Belum efektifnya tindak lanjut penanganan kasus yang telah diserahkan oleh Bank Indonesia kepada penyidik;

4. Terdapat beberapa kasus yang sulit diungkapkan modus operandinya yang antara lain disebabkan oleh pesatnya kemajuan atau perkembangan teknologi informasi.

Tentu saja kendala-kendala tersebut bukan hanya untuk direnungkan saja, akan tetapi perlu dicarikan solusinya, mengingat kendala yang dikemukakan Sitompul itu berada pada jajaran penegak hukum dari hulu sampai hilir. Dari sisi perundang-undangan yang mestinya dibuat fleksibel untuk menerima segala bentuk perkembangan baru dari teknologi untuk dijadikan barang bukti sampai kepada persidangan di pengadilan yang sarat dengan korupsi, kolusi dan nepotisme, serta ketegasan Bank Indonesia dalam memberi sanksi kepada bank yang melakukan kejahatan.

Sampai saat ini, sebenarnya Bank Indonesia sebagai salah satu pihak yang memberikan sanksi administrasi kepada perbankan yang melakukan tindak pidana telah melakukan kerjasama dengan berbagai pihak, misalnya dengan KPK, PPATK, Kepolisian dan pihak-pihak lainnya, termasuk perguruan tinggi. Kerjasama itu dilakukan dalam berbagai bentuk, misalnya penelitian/ pengkajian data nasabah terpadu, pertukaran informasi dan bantuan konsultasi, bantuan personil, pelatihan dan sosialisasi, disediakannya pejabat penghubung, dan pemeriksaan khusus bersama BI-KPK pada bank umum dalam rangka penyelamatan keuangan negara. ${ }^{17}$

Pencegahan dan penanggulangan tindak pidana dalam kerangka kebijakan kriminal dapat dilakukan dengan 2 (dua) cara, yaitu penal (penal policy) dan non penal (non penal policy). Penal policy lebih ditekankan kepada upaya represif dari penegak hukum yang didahului dengan ketersediaan undang-undangnya. Penal policy menjadi tugas polisi, jaksa, hakim, dan tentunya Bank Indonesia yang dalam hal kaitannya dengan pelanggaran administrasi. Sedangkan non-penal

\footnotetext{
${ }^{15}$ Agus Raharjo, Op.Cit.

${ }^{16}$ Ibid.

${ }^{17}$ Ibid.
} 


\section{$\mathcal{H}$ urnal Negara dan Keadilan \\ p-ISSN 2302-7010 e-ISSN 2721-9801}

policy, menjadi tugas dari aparat penegak hukum, Bank Indonesia, bank pemerintah maupun swasta dan masyarakat.

Proses Pencegahan dan penanggulangan kejahatan bukan sekadar terbatas pada upaya penal yang seringkali bersifat represif, akan tetapi akan lebih efektif jika dikaitkan langsung dengan karakteristik yang khas dari tindak pidana tersebut. Misalnya, pada tindak pidana perbankan, ciri yang khas adalah pada perhitungan alur masuk dan keluar uang dari nasabah, dan ilmu yang tepat untuk mengetahui kewajaran atau ketidakwajaran atas alur ini adalah akuntansi. Penilaian yang tepat dari ilmu ini akan mencegah secara lebih dini terjadinya tindak pidana perbankan.

Secara spesifik, Setiadi dan Yulia, ${ }^{18}$ menyebutkan bahwa dalam rangka penegakan hukum dan pencegahan kejahatan perbankan, maka langkah-langkah yang harus ditempuh adalah sebagai berikut:

1. Perlunya peningkatan kemampuan penyidik dalam bidang akunting dan keuangan;

2. Sistem pengawasan dari pihak bank yang efektif dan ini bisa dilakukan kalau rekruitmen pegawai lebih menekankan kepada mental idiologi;

3. Perlunya kewenangan penyidik dalam rangka menjalankan tugasnya, bukan hanya sekadar menyangkut rahasia bank;

4. Perlunya pembaharuan perundang-undangan dalam bidang ekonomi, in casu undang-undang perbankan.

Peran bank dalam kegiatan ekonomi amatlah sentral, dan mengingat posisi yang demikian pembinaan dan pengawasan yang efektif terhadap setiap aktivitas perbankan sangat diperlukan. Hal ini perlu dilakukan mengingat pembinaan dan pengawasan yang efektif yang didasari oleh gerak yang kokoh dari lembaga perbankan akan membuat perbankan Indonesia mampu bersaing di era global secara efisien, sehat, wajar, dan mampu melindungi dan menyalurkan dana masyarakat secara baik.

Bank sebagai lembaga ekonomi melakukan dua kegiatan pokok, yaitu menghimpun dana dari masyarakat dalam bentuk simpanan dan menyalurkannya ke masyarakat dalam bentuk kredit atau bentuk lain dalam rangka meningkatkan taraf hidup masyarakat. Sebagai tempat perputaran uang, bank memiliki kedudukan yang rentan terhadap penyalahgunaan kewenangan, baik oleh pihak bank sendiri maupun oleh pihak luar yang memanfaatkan bank sebagai tempat untuk dapat menyembunyikan hasil kejahatannya. ${ }^{19}$ Oleh karena itu, pihak bank mempunyai peran yang sangat menentukan pertahadap kuantitas dan kualitas penanggulangan tindak pidana perbankkan yang selama ni terjadi di Indonesia.

\section{PENUTUP}

Modus operandi merupakan bagian dari tindak pidana perbankkan di Indonesia sebagaimana tercantum dalam ketentuan dalam UU Perbankan yang menetapkan tiga belas jenis tindak pidana yang sebagaimana diatur dalam Pasal 46 sampai dengan Pasal 50A. Ketiga belas tindak pidana itu dapat digolongkan ke dalam empat jenis berikut ni, pertama,tindak pidana yang berkaitan dengan perizinan, kedua,tindak Pidana yang berkaitan dengan rahasia bank, ketiga,tindak

\footnotetext{
18 Yulia dan Setiadi, Op.Cit, hal. 145-146.

${ }^{19}$ Agus Raharjo, Op.Cit.
} 


\section{Jurnal Negara dan $\mathcal{X}$ eadilan \\ p-ISSN 2302-7010 e-ISSN 2721-9801}

pidana yang berkaitan dengan pengawasan dan yang terakhir pembinaan dan tindak pidana yang berkaitan dengan usaha bank.

Upaya penanggulangan tindak pidana perbankkan tidak sekadar terbatas pada upaya penal policy yang seringkali bersifat represif, akan tetapi akan lebih efektif jika dikaitkan langsung dengan karakteristik yang khas dari tindak pidana tersebut. Upaya-upaya tersebut sebagai berikut, pertama, Perlunya peningkatan kemampuan penyidik dalam bidang akunting dan keuangan, kedua,peningkatan sistem pengawasan dari pihak bank yang lebih efektif dan ini bisa dilakukan kalau rekruitmen pegawai lebih menekankan kepada mental idiologi, ketiga,Perlunya kewenangan penyidik dalam rangka menjalankan tugasnya, bukan hanya sekadar menyangkut rahasia bank semata dan yang terakhir perlunya pembaharuan peraturan perundang-undangan dalam bidang ekonomi, in casu undang-undang perbankan.

\section{Peraturan Perundang-undangan}

\section{DAFTAR PUSTAKA}

Undang-undang Dasar Negara Republik Indonesia Tahun 1945

Undang-Undang Republik Indonesia No. 7 Tahun 1992 tentang Perbankkan

Undang-Undang Republik Indonesia No. 10 Tahun 1998 tentang Perbankan

\section{Buku}

Abdulkadir Muhammad, Etika Profesi Hukum, Citra Adtya, Bandung, 1997.

Sunardi dan Fanny Tanuwijaya., Tindak Pidana Nyawa Badan Lembaga Penerbitan Fakultas Hukum Unisma, Malang.

Abdul Wahid, Kriminologi dan Kejahatan Kontemporer, Visipres dan Lembaga Penerbitan Fakultas Hukum Unisma, Malang.

Al-Hilal Hamdi, Menjelajah Dunia Hukum, LPP-Mpres, Jakarta, 2007.

A.Qirom Syamsudin dan E. Sumaryono, Kejahatan Anak, Suatu Tinjauan Psikologi, Liberty, Yogyakarta, 1980.

Arif Gosita, Masalah Korban Kejahatan (Kumpulan Karangan), Edisi Keempat. Jakarta: Badan Penerbit FH UI, 2007

Buletin BI, Hukum Perbankan dan Kebanksentralan, ISSN, Jakarta, 2012,

CST. Kansil, Pengantar Ilmu Hukum dan Tata Hukum Indonesia, Balai Pustaka, Jakarta, 2000.

Edi Setiadi dan Rena Yulia. Hukum Pidana Ekonomi. Yogyakarta: Graha Ilmu, 2010.

G. Widiartana, Viktimologi Perspektif Korban dalam Penanggulangan Kejahatan. Yogyakarta: Universitas Atmajaya, 2009.

Hary Saherodji, Pokok-pokok Kriminologi, Aksara baru, Jakarta, 1980.

Jean-Francois Arvis and Ronald E. Berenbeim, Fighting Corruption in East Asia Solition from the Private Sector, (Washington, D.C.: The World Bank, 2003.

Kartini Kartono, Patologi Sosial Jilid I, Rajawali Pres, Jakarta, 1987.

Lenden Marpaung, Kejahatan Perbankan, Erlangga, Jakarta, 1993.

L.J. Van Apeldoorn, Pengantar Ilmu Hukum, Djambatan, Jakarta, 1986.

Moh. Fahmi, Indonesia sebagai Sarang Penyamun, Media Kedaulatan, 2011 


\section{$\mathcal{H}$ urnal Negara dan Keadilan \\ p-ISSN 2302-7010 e-ISSN 2721-9801}

Moeljatno, Asas-asas Hukum Pidana, Roneka Cipta, Jakarta, 1993.

P.A.F. Lamintang, Dasar-Dasar Hukum Pidana Indonesia, Bandung, Citra Aditya Bakti, 1997.

Pratywi Precilia Soraya, Pencegahan Dan Pemberantasan Kejahatan Perbankan Melalui Sarana Pengawasan Lex Crimen Vol. II/No. 2/Apr-Jun/2013.

Simanjuntak, Kriminologi, Tarsito, Bandung, 1992

Soerjono Soekanto, Pengantar Penelitian Hukum, Sinar Grafika, Jakarta, 1986. \& Sri Mamudji, Penelitian Hukum Normatf, Rajagrafindo Persada, Jakarta, 2003. 